\title{
Stylistics and Linguistic Variations in Forough Farrokhzad's Poems
}

\author{
Ferdows Aghagolzade \\ Dept of Language and Linguistics, University of Tarbiyat Modares, Tehran, Iran \\ Email: aghagolz@modares.ac.ir \\ Masoud Dehghan \\ Dept. of Language and Linguistics, Univ. of Tarbiyat Modares, Tehran, Iran \\ Email: dehghan_m85@yahoo.com
}

\begin{abstract}
Stylistics is one of the most important issues in literary text. Its goal is to decode literary meanings and structural features of literary texts by identifying linguistic patterns and their functions in the texts. The aim of this study is to survey the theory of stylistics and its practical application at Forough Farrokhzad's poems. The presented study investigates stylistic devices at works which have been published in five volumes, entitled "The Captive" [Asir], "The Wall" [Divar], "Rebellion" [Esian], "Another Birth" [Tavallodi Digar], "Let Us Believe in the Beginning of the Cold Season" [Iman biyavarim be Aghaz-e Fasl-e Sard]. Literary work can evaluate contract stylistics from various dimensions as this paper examines several stylistic devices and linguistic variations such as "rhyme", "alliteration", "repetition", "assonance", and "onomatopoeia" at Farrokhzad's poems. Stylistics and linguistic variation at Forough Farrokhzad's poems are the fundamental issues at this article. These concepts like other feelings and affections of mankind are the main theme sections of the contemporary literature. In the next section, this paper investigates several themes found among Farrokhzad's poems. In general, the main goal of the article is that the reader by deliberation at poetical samples of Forugh and other lateral discussions - which are presented in various parts of the article- be able to figure out the approach and attention of Forugh on the used concepts in her verses about separation, lack of happiness, sin, disobedience, deliverance of self, etc.
\end{abstract}

Index Terms - stylistics, linguistic variation, Farsi verses, individual feelings, Forough Farrokhzad

\section{INTRODUCTION}

Forough Farrokhzad, as a modern Iranian poet, occupies an especial position among Iranian poets at twentieth century. Her poems manifest a singular voice of a lonely Iranian woman. In her poems, she was going to challenge the social and patriarchal boundaries. Clearly her poems show a conscious attempt to take limitations imposed on Iranian women. This paper investigates the considerable body of poetry about five volumes that Farrokhzad warbled in her short lifetime. In fact, Farrokhzad's poems and her life are a movement towards the liberation of self. A lot of titles among her volumes present various stages in her movement towards self empowerment. This paper surveys the stylistic and linguistic variation at Farrokhzad's poems. In her poems, she wrote more frankly about sex and more forcefully about desire than any Iranian literary figure before or since. And she paid a heavy price for it.

In 1955, Farrokhzad's first volume, entitled Asir (The Captive), comprises forty-four poems was published. In 1956, she left Iran to Europe. In this year, she published the second volume of her poems, comprising twenty-five poems, titled Divar (The Wall), dedicated to her former husband. In 1958 her third volume, titled Esian (Rebellion), was published which manifests her encounter of patriarchal imposition on female identity. Also, in this volume, her vision has moved from her first and second volume to a new phase that she states it according to her words, 'the desperate struggle between two stages of life, the last gasps before a kind of letting go'. 'This letting go' will finally cause to publish her best volume, entitled 'Another birth' [Tavallodi Digar]. Another two volumes mark her self - invented identity which one of them was published in 1964, called Tævællodi digær (another birth), comprised thirty-five poems. In this volume (1964), Farrokhzad moved beyond the area of personal experience to place individuals (or perhaps just herself) within the context of a larger social struggle.

The last volume was published after her death, titled Iman biyaværim be Aghaz-e Fæsl-e Særd (Let Us Believe in the Beginning of the Cold Season). In the poem 'someone like no oneelse' (1965) that there is in the volume, entitled Iman biyavarim be Aghaz-e Fasl-e Sard (Let Us Believe in the Beginning of the Cold Season), which was published after her death, we can see Farrokhzad as simultaneously the individual, the social creature, and the poet.

Farrokhzad's earlier poems were weak in form and without approximately imagery, but they reflected the sorrows and the pains of contemporary Iranian women, who felt drowned in their innocent youth and limited to a repressed life behind the curtains of customs and traditions. Furthermore, the speaker's almost exclusive focus on himself is suggested by the fact that the first person pronoun 'I', and the corresponding possessive determiner 'my'. 


\section{SignificAnce OF THE StUdy}

The present study attempts to provide a comprehensive theoretical background to the study of stylistics. The aim of this paper is to provide the person interested in the theory of stylistics and its practical application in literary text analysis. By means of working with a wide variety of texts including literary works, poems, and etc., stylistics can function as a bridging discipline between literary and linguistic courses. In general, this paper focuses on linguistic aspects of stylistic survey. In addition, it recognizes several themes in this poetry. In $\S$ B below, provides a good framework for analyzing this issue.

\section{THE POEM}

Forough Farrokhzad, as a female divorcee writing controversial poetry with a strong feminine voice, was born in Tehran to career military officer Colonel Mohammad Bagher Farrokhzad and his wife Touran Vaziri-Tabar in 1935. The third of seven children (Amir, Massoud, Mehrdad, Fereydoun Farrokhzad., Pouran, Gloria), she attended school until the ninth grade, and then was taught painting and sewing at a girl's school for the manual arts. At the age of 16 she was married to Parviz Shapour, an acclaimed satirist. Farrokhzad continued her education with classes in painting and sewing and moved with her husband to Ahvaz. A year later, she bore her only child, a son named Kamyar (subject of $A$ Poem for You).

Within two years, in 1954, Farrokhzad and her husband divorced; Parviz won custody of the child. She moved back to Tehran to write poetry and published her first volume, entitled 'The Captive' [Asir], in 1955.

She was an Iranian poet and film director. Forugh is arguably one of Iran's most influential female poets of the $20^{\text {th }}$ century. She was a controversial modernist poet and an iconoclast. She lived at a time where women generally performed as subordinates to the male race.

\section{THEORETICAL FRAMEWORK}

According to J. Mistrik (1985) stylistics is regarded as a field of study "where the strategies of choice and implementing linguistic, paralinguistic or aesthetic expressive devices in the process of communication" are investigated (p.30). J. Mistrik (1985) defines "stylistics or text analysis as a procedure which aims at the linguistic devices and means of a given text, the message, topic and content of analyzed texts aren't the focus" (p. 31). The method of stylistic analysis can be equally applied to the study of language use in literary as well as non-literary texts. So, in general, style can be seen as a variety in language use, whether literary or non-literary.

Stylistic features are basically features of languages. So style is in one sense synonymous with language. Stylistics is the study of style. It can be viewed in several ways. This variety in it is because of the basic effects of linguistics and literary criticism. This term replaces the earlier discipline known as rhetoric in the $20^{\text {th }}$ century.

In general, the aim of most stylistic studies is to illustrate their functional importance for profiling of the text, novels, poetry, and etc. Also, the study of stylistics is related to the field of study of linguistics as well as literary study.

By reference to the style of $\mathrm{X}$, for instance, we talk about the characteristics of language use, and also correlating these with some extra linguistic X, that we might call the stylistic DOMAIN. (Leech \& Short, 1981)

Widdowson (1975) defines stylistics as the "study of literary discourse from a linguistic orientation" which "treats literature as discourse" (pp. 3-6). Toolan (1998) supports this view by saying that stylistics is "the study of language in literature" and that it is therefore part of linguistics (p. viii)

Stylistics is defined as the linguistic analysis of literary texts and therefore as a linguistic discipline. Its goal is to decode literary meanings and structural features of literary texts by identifying linguistic patterns and their functions in the texts. Consequently, the term style means "lexical and grammatical patterns in a text that contribute to its meaning". (Austen, 2010, p. 2)

The following table offers a summary of the most common definitions of style and the most influential approaches in stylistic studies: 
TABLE 1.

STYLE AND STYLISTICS (GABRIELA MIŠŠIKOVA, 2003, P. 20)

\begin{tabular}{|l|l|}
\hline DEFINITIONS OF STYLE & APPROACHES IN THE STUDY \\
OF STYLISTICS
\end{tabular}

N. E. Enkvist (1973) states, linguistic stylistics attempts to set up descriptions of stylistic motives "with the help of linguistic concepts" (pp. 16-17). According to this definition, linguists should be interested in all types of linguistic variation and style is only one of many types. The table below presents the classification of linguistic variations according their correlation towards context, situation and others:

TABLE 2.

TYPES OF LINGUISTIC VARIATION (GABRIELA MIŠŠIKOVA, 2003, P. 23).

\begin{tabular}{|c|c|}
\hline STYLE & $\begin{array}{l}\text { - correlates with context and situation, } \\
\text { - is an individual variation within each register. }\end{array}$ \\
\hline TEMPORAL & - correlates with a given period. \\
\hline REGIONAL & - correlates with areas on a map. \\
\hline SOCIAL DIALECT & $\begin{array}{l}\text { - correlates with the social class of its users, } \\
\text { - also called sociolect. }\end{array}$ \\
\hline IDIOLECT & - indicates the language of one individual. \\
\hline REGISTER & $\begin{array}{l}\text { - correlates with situations, } \\
\text {-different subtypes of language that people use in different social roles (e.g. doctor's register is } \\
\text { different from the teacher's, etc.). }\end{array}$ \\
\hline
\end{tabular}

\section{DATa Analysis}

In this part, the present study will address the role and the importance of stylistic devices as the most important tools of transferring ideologies, views and judgments in literary texts. Then this study will survey the verses stanza at Farrokhzad's poems.

This paper investigates all volumes at Farrokhzad's poems and after studying them, it will show that there are some stylistics and linguistic devices at them as we can see below. In other words, The present study surveys these devices at Forough's works which have been published in five volumes, entitled 'The Captive' [Asir], 'The Wall' [Divar], 'Rebellion' [Esian], 'Another Birth' [Tavallodi Digar], 'Let Us Believe in the dawn of the Cold Season' [Iman bijavarim be Aqaz-e Fasl-e Sard].

In addition to stylistic devices, this paper recognizes several THEMES in Farrokhzad's poems; such as 'separation', 'sin', 'Free and disobedience', 'lack of happiness'.

\section{A. The Major Stylistic Devices}

Stylistics is the linguistic analysis of literary texts. There are some stylistic devices at the volumes of Farrokhzad's poems that I have studied. And some of these stylistic devices are 'rhyme', 'alliteration' 'repetition', 'assonance' and 'onomatopoeia'. (Miššikova, 2003, pp. 92-97). So this paper considers these devices at Farrokhzad's poems in order to study them.

\section{Rhyme}

The repetition of identical or similar sounds, usually accented vowel sounds and succeeding consonant sounds at the end of words, and often at the ends of lines of prose or poetry.

It has several functions:

- it adds a musical quality to the poem; 
- it makes the poem easier to remember;

- it affects the pace and tone of the poem.

Two or more verse lines make a stanza, so a stanza is a verse segment composed of a number of lines. The ballad stanza has four lines, only the second and the fourth lines rhyme.

\subsection{The Use of the Stylistic Device 'Rhyme'}

The extracted poem from the Captive's volume has some words in lines two and four which are rhyme together at the end of them:

to ra mixahæm-o- danæm ke hærgez

be kam-e del dær aqušæt nce fircem,

to?e ?an ?aseman-e saf-o- rowšæn,

mæn Pin kondb-e Gæfæs, morqi cesircem.

ze pošt-e mileha-je særd-o- tireh

negah hæsrætæm hajran be rujcet

dær ?in fekræm ke dæsti piš ?ajæd

væ mæn nagæh gošayæm pær be sujcet.

dær Pin fekræm ke dær jek læhze qeflæt,

?æz ?in zendan xamoš pær be fircem,

be čæšm maerd zendanban bexændæm,

kenaræt zendegi ?æz sær be fircem.

dær Pin fekræm mæn-o- danæm ke hærgez,

mæra jara-je ræftæn zin Gæfæs nist,

?ægær hæm mærd-e zendanban bexahæd,

degær ?æz bæhr-e pærvazæm næfæs nist.

Translation

I want you, yet I know that never

can I embrace you to my heart's content.

you are that clear and bright sky.

I, in this corner of the cage, am a captive bird.

from behind the cold and dark bars,

directing toward you my rueful look of astonishment,

I am thinking that a hand might come,

and I might suddenly spread my wings in your direction.

I am thinking that in a moment of neglect,

I might fly from this silent prison,

laugh in the eyes of the man who is my jailer,

and beside you begin life anew.

I am thinking these things, yet I know,

that I cannot, dare not leave this prison,

even if the jailer would wish it,

no breath or breeze remains for my flight.

As we consider, at the above second and forth lines, the words'nægiræm' / '?æsiræm' and 'rujœet'/ 'sujcet' are rhyme.

\section{Alliteration}

It is the repetition of similar sounds (usually consonants) at the beginning of successive words. In other words, Alliteration is the repetition of initial consonant sounds in two or more neighboring words or syllables. We find alliteration in many familiar phrases and expressions.

\subsection{The Use of the Stylistic Device 'Alliteration'}

The elaborate parallelistic structure of the following verses has been displayed by placing the parallelisms, or structural equivalences. The parallelisms are reinforced by frequent alliteration, indicated by italics below:

gonceh kcerdcem gonahi por ze lezæt

dær ?aquši ke gærm-o-Patcešin bud

gonceh kaerdaem mijan bazoW-ani

ke daq-o- kine dguj-o- ?ahcenin bud 
doer Pan xaelvaetgceh-e tarik-o- xamoš

negæh kærdæm be čœšm-e por ze razœš

delæm dær sine bitabane lærzid

ze xahešhaj-e čcešm-e por nijazaš

doer Pan xaelvatgah-e tarik-o-xamoš

pærišan dær kenar-e ?u nešæstæm

læbæš bær ruj-e læbhajæm hævæs rixt

ze ?ænduh-e del divane ræstæm

Translation

I sinned a sin full of pleasure,

in an embrace which was warm and fiery.

I sinned surrounded by arms

that were hot and avenging and iron.

in that dark and silent seclusion

I looked into his secret-full eyes.

my heart impatiently shook in my breast

in response to the request of his needful eyes.

in that dark and silent seclusion,

I sat disheveled at his side.

his lips poured passion on my lips,

I escaped from the sorrow of my crazed heart.

\section{Repetition}

Repetition is the deliberate use of a word or phrase more than once in a sentence or a text to create a sense of pattern or form or to emphasize certain elements in the mind of the reader or listener. Here are further kinds of repetition like parallelism, which is the repeating of a structure.

\subsection{The Use of the Stylistic Device 'Repetition'}

dær Pin fekræm ke dær jek læhzæ-je qeflæt,

Pæz Pin zendan xamoš pær befiræm,

be čæšm mard zendanban bexændæm,

kenaræt zendegi ?æz sær befiræm.

dær Pin fekræm mæn-o- danæm ke hærgez,

mæra jara-je ræftæn zin Gæfæs nist,

1ægær hæm mærd-e zendanban bexahæd,

degær Pæz bæhr-e pærvazæm næfæs nist.

Also the following extracted verses from the volume of 'Another birth' [Tavallodi Digar] show the use of this stylistic device:

hæme midanænd

hæme midanænd

ke moen-o- to ?æz ?an rowzæneh-je særd-e ?æbus

baq ra didim

væ ?æz $2 a$ n šaxe-je bazigær dur ?æz dæst

sib ra čidim

hæme mitarsænd

hæme mitarsænd, ?æma mon-o- to

be čeraq-o- $2 a$ b-o- $2 a$ yene pejvæstim

væ nætærsidim.

Translation:

everyone knows,

everyone knows

that you and I have seen the garden

from that cold sullen window

and that we have plucked the apple

from that playful, hard-to-reach branch.

everyone is afraid 
everyone is afraid, but you and I

joined with the lamp and water and mirror

and we were not afraid.

\section{Assonance}

It is similar to alliteration in which vowels are repeated. In other words, Assonance is the repetition of vowels in nonrhyming words. It is used in modern English-language poetry, and also in Old French, Spanish and Celtic languages.

4.1 The use of the stylistic device 'assonance'

to $\mathrm{r} a$ mix choem-o- dancem ke horgez

be kam del d $c e r$ aqušcet n $c e f i r c e m$,

to 1 e $?$ an $?$ aseman-e saf- $o$ - rowšcen,

man Pin kond-e q ef $c e s$, morqi icesircem.

ze pošt-e mileha-je scerd-o- tireh

negch hoesrcetcem hæjron be rujœet

$\mathrm{d}$ er Pin fekrcem ke daesti piš Pajced

vøe meen nageh gošajoem pcer be sujcet.

Translation

I want you, yet I know that never

can I embrace you to my heart's content.

you are that clear and bright sky.

I, in this corner of the cage, am a captive bird.

from behind the cold and dark bars

directing toward you my rueful look of astonishment,

I am thinking that a hand might come

and I might suddenly spread my wings in your direction

\section{B. The Major Themes}

There are some themes in volumes of Farrokhzad's poems that we have studied. Some of these themes are 'seperation', 'sin', 'free and disobedience' 'lack of happiness', 'feministic mood', etc. The present study considers these themes at Farrokhzad's poems to analyze them. Thus these themes will be analyzed below.

\section{The Seperation [Jodaee]}

Farrokhzad's first stage of disobedience was that time she was going to separate from her husband and decided to live lonely without any male in her real life. In this volume (1958), Farrokhzad illustrates a woman found the selfconfidence to stand before Iranian society as an individual.

\section{The Sin [Gon $\square \mathrm{h}]$}

The most scandalous of these poems is 'sin', first published in a magazine and later included in her second collection, 'The Wall'. It is a quatrain sequence with vivid sexual imagery. Also, as we consider in this poem, Farrokhzad enjoys committing a sexual sin from an intimately feminine point of view.

She had several short lived relationships with men and the verses 'Gonah' [The sin] extracted from the second volume 'The Wall' expresses one of them. In addition, the importance of Farrokhzad is for the sake of being the first modern Iranian woman to graphically articulate private sexual landscapes from a woman's perspective, as in 'gonæh kærdæm' [I Sinned] printed below.

gonæh kærdæm gonahi por ze lezæt

dær Raquši ke gærm-o-Patæšin bud

gonæh kærdæm mijan bazo-v-ani

ke daq-o- kine guju-o- ?ahænin bud

dær ?an xælvætgæh-e tarik-o- xamoš

negæh kærdæm be čæšm-e por ze razæš

delæm dær sine bitabane lærzid

ze xahešhaj-e čæšm-e por nijazæš

dær ?an xælvætgæh-e tarik-o- xamoš

pærišan dær kenar-e ?u nešæstæm

læbæš bær ruj-e læbhajæm hævæs rixt

ze ?ænduh-e del divane ræstæm 
foru xandæm be gušæš qese-je ?ešq

to ra mixahæm ?ay jananæ-ye mæn

to ra mixahæm ?aj Raquš-e đ̧anbæxš

to ra ?æj ?ašeq-e divanæ-je mæn

hævæs dær dideganæš šo?le ?æfruxt

šærab-e sorx dær pajmane ræGsid

tæn-e mæn dær mijan bestær-e nærm

be ruj-e sine?æš mæstane lærzid

gonæh kærdæm gonahi por ze lezæt

kenar-e pajkæri lærzan-o- mædhuš

xodavænda če midanæm če kærdæm

dær ?an xælvætgæh-e tarik-o- xamoš

Translation

I sinned, a sin full of pleasure,

In an embrace which was warm and fiery;

I sinned surrounded by arms

that were hot and avenging and iron.

In that dark and silent seclusion

I looked into his secret-full eyes.

my heart impatiently shook in my breast

In response to the request of his needful eyes.

In that dark and silent seclusion,

I sat disheveled at his side.

his lips poured passion on my lips,

I escaped from the sorrow of my crazed heart.

I whispered in his ear the tale of love:

I want you, $\mathrm{O}$ life of mine,

I want you, O life-giving embrace,

$\mathrm{O}$, crazed lover of mine, you.

desire sparked a flame in his eyes;

the red wine danced in the cup.

In the soft bed, my body

drunkenly quivered on his chest.

I sinned a sin full of pleasure,

next to a shaking, stupefied form.

O God, who knows what I did

in that dark and quiet seclusion.

Also, one of the verses in the volume of 'Asir' [The captive], entitled 'Dive šæb' [The demon of the Night], reprehending Forough for the sin that she has committed, and the infernal spirit of darkness says to her:

divæm ?æma to ?æz mæn divtæri

madær-o damæn-e næng ?allude?

Oh! bærdar særæš ?æz damæn

teflæk-e pak kođa ?asude

Translation

I am a demon, but you are a worse demon than I

a mother, and yet unchaste?

oh! how dare you to let the poor pure child

lay his head on your stained lap.

\section{Free and disobedience}

There are some "helping verbs" like can, will may, might, etc. (Halliday, 1982). These modal verbs act upon the time reference of the verbal groups in which they take place, taking it to the realm of the possible, probable, or necessary. So the time reference of these modal verbs isn't the time actually happened, but to the imaginary. She knew that women like her wished to free themselves from the prison of veiled chastity and forced modesty, and to shout out, among other things, their natural desires. 
Farrokhzad's first volume of verse, The Captive, was composed before her divorce and her separation from her boy. The verses in this volume show her feeling of putting in the constraints of a traditional married life in Iran. In addition, the majority of her poems in this volume, 'The Wall' [Divar], are about the concept of slavery imposed by society and love. Furthermore, these verses indicate Farrokhzad's inner contradictions regarding making a selection between her maternal duties and the following of her artistic aspiration. The decision wasn't so easy for her since she suffered from disobedience against her patriarchal definitions as an Iranian woman. Forough states her feeling about traditional and conventional marriage in this volume and she voices as a wife no longer able to live in a limited life as 'the Captive', 'The wedding Band', 'Call to Arms', and 'To my Sister'.

to ra mixahæm-o- danæm ke hærgez

be kam-e del dær Paqušæt næfiræm

to?e ?an ?aseman-e saf-o- rowšæn

mæn Pin konњb-e Gæfæs, morqi 1æsiræm

ze pošt-e mileha-ye- særd-o-tire

negah-e hæsrætæm hæjran be rujæt

dær ?in fekræm ke dæsti piš ?ajæd

væ mæn nagæh gošajæm pær be sujæt

dær Pin fekræm ke dær jek læhze qeflæt

?æz ?in zendan xamoš pær befiræm

be čæšm-e mærd-e zendanban bexændæm

kenaræt zendefi Pæz sær befiræm

dær Pin fekræm mæn-o danæm ke hærgez

mæra jara-je ræftæn zin Gæfæs nist

Pægær hæm mærd-e zendanban bexahæd

degær ?æz bæhr-e pærvazæm næfæs nist

ze pošt- e mileha hær sobh-e rowšæn

negah-e kudæki xændæd be rujæm

čo mæn sær mikonæm ?avaz-e šadi

læbæš ba buse miajæd be sujæm

?ægær 1æj ?aseman, xahæm ke jek ruz

?æz Pin zendan-e xamoš pær befiræm

be čæšm-e kudæk-e gerjan če gujæm

ze mæn bogzær ke mæn morqi ?æsiræm

mæn Pan šæm?æm ke ba suz-e del-e xiš

foruzan mikonæm virane?æm ra

Pægær xahæm ke xamuši gozinæm

pærišan mikonæm kašane?æm ra

\section{Translation}

I want you, yet I know that never can I embrace you to my heart's content.

you are that clear and bright sky.

I, in this corner of the cage, am a captive bird.

from behind the cold and dark bars

directing toward you my rueful look of astonishment,

I am thinking that a hand might come

and I might suddenly spread my wings in your direction.

I am thinking that in a moment of neglect

I might fly from this silent prison,

laugh in the eyes of the man who is my jailer

and beside you begin life anew. 
I am thinking these things, yet I know

that I cannot, dare not leave this prison.

even if the jailer would wish it,

no breath or breeze remains for my flight.

from behind the bars, every bright morning

the look of a child smile in my face;

when I begin a song of joy,

his lips come toward me with a kiss.

$\mathrm{O}$, sky if I want one day

to fly from this silent prison,

what shall I say to the weeping child's eyes:

forget about me, for I am captive bird?

I am that candle which illumines ruins

with the burning of her heart.

If I want to choose silent darkness,

I will bring a nest to ruin.

[Extracted from 'The captive' [Asir]]

\section{Lack of happiness}

In one of her another verses in this volume, titled 'X $\square$ næ- ye Mætruke' [The Deserted Home], she confesses that their home has been deprived of the happiness after the separation from her husband and her boy and she says:

I know that now a child is crying,

full of sorrow of separation from his mother;

but, wounded at heart and distressed,

I am on the path of my desire.

my friend and my beloved is poetry

and I go to find it.

\section{Feministic mood}

No one can deny the feministic mood of her poetry. This feministic mood is one of the many reactions women of Iran adopted as a result of the patriarchal society they lived in. Nevertheless, we must keep in mind that the research of women in Iran has advanced and developed during the last thirty years, producing a great deal of expressive and analytical reviews (AFKHAMI, 1994, pp. 5-18). The Following verses are from Farrokhzad, 1982, p. 34.

I saw the marrow of my being

melting

in the movement of his hands

I saw his heart

held holly by the vagrant charmed

echoing of my heart

\section{CONCLUSION}

This paper focuses on the use of linguistic variation in Farrokhzad's poems, and demonstrates the usefulness of stylistic analysis in investigating the nature and potential effects of such variation in this particular poem. The analysis of her poems has focused in detail on the way in which the language of the poem conveys the impression of (i) a particular speaking voice in a specific setting, (ii) a particular non-literary written register, and, potentially, (iii) an ironic voice. Furthermore, what the present study concludes is to illustrate Farrokhzad's feelings and attitudes in the poems of her volumes and also expresses various stages of her life, which this paper surveys those stages as themes in Forough's poems. In her volumes, we can see that the happiness has left their home after her separation of her husband and her boy. Also, we can understand from her volumes that she have had various carnal relationships with men. As well as, some of her volumes show that she rebels from the social conventions and permanently defends from women rights as a feminist. So, she is the first to claim victory over the male dominated society in Iran's modern poetry. She pioneered as the feminine voice of Iranian poetry, and in her short-lived life, she accomplished more than ever expected.

\section{REFERENCES}

[1] Afkhami, M. (1994). Women in Post-Revolutionary Iran: a Feminist Perspective. In the Eye of the Storm. London, England: I.B.Tauris Publishers,5-18.

[2] Austen, J. (2010). How to Do Things with Words. Oxford, Clarendon Press, 2.

[3] Austen, J. etal. (2010). Corpus linguistics in literary analysis. Continuum International Publishing Group. Replika Press Pvt Ltd.

[4] Enkvist, N. E. (1973). Linguistic Stylistics. The Hague and Paris, Mouton, 17-16

[5] Farrokhzad, F. The Collection of Forough's Poems. Iran International Library. 
[6] Halliday, M. A. K. (1992). Language as system and language as instance: the corpus as a theoretical construct. In J. Svartvik (ed.), Directions in Corpus Linguistics.

[7] Halliday, M. A. K. (1991). Corpus studies and probabilistic grammar. In K. Aijmer and B. Altenberg (eds), English Corpus Linguistics. London: Longman.

[8] Leech, Geoffrey, N. and Michael, H. SHORT. (1981). Style in Fiction. London: Longman.

[9] Miššikova, G. (2003). Linguistics stylistics. Univerzita Konštantinafilozofa Nitra, 97-92

[10] Mistrík, J. (1985). Stylistika. the most comprehensive book on Slovak stylistics, 30- 31

[11] Toolan, M. (1998). Language in Literature: an Introduction to Stylistics. London, New York: Arnold, Viii.

[12] Widdowson, H. G. (2004). Text, Context, and Pretext: Critical Issues in Discourse Analysis. Oxford: Blackwell.

[13] Widdowson, H. G. (1975). Stylistics and the Teaching of Literature. Longman: London, 6-3

Ferdows Aghagolzade Ph.D. Associate professor at Univ. of Tarbiyat Modares, Dept. of Language and Linguistics, Tehran, Iran. $\mathrm{He}$ is from Iran and he was born there. He has Ph.D. degree in Linguistics from the Department of language and linguistics at Tarbiyat Modares University in Iran. Also, He has many researches which has done before. Email: aghagolz@modares.ac.ir

He's taught language and linguistics to students at Tarbiat Modares University in Tehran, Iran since 1998. Also, he has many researches.

Masoud Dehghan Ph.D. Candidate at Univ. of Tarbiyat Modares, Dept. of Language and Linguistics, Tehran, Iran. He is teaching English Language at Dept. of English Language and literature, Razi Univ., Kermanshah, Iran. Also, he's teaching English Language at university of Applied, Science and Technology in Kermanshah, Iran. Email: dehghan_m85@yahoo.com.

His previous researches are: 1- "Discourse and Otherness: A critical Study of the other in the Recent Discourse on Democracy". Int. Conference on CDA. University of Tasmania. February in 2005. 2- "A short analysis of Insertion in Persian". Theory and Practice in Language Studies, Vol. 2, No. 1, pp. 14-23, January 2012. 3- "On Type: The So-Called Causativization in Persian". TPLS academy publisher. Volume2, Issue 7. July, 2012. 4- "The Otherness: The Discourse of Democracy in Bush's Orations after 9/11"Archive Des Sciences Journal, ISI Journal. Switzerland. July, 2012. 